\title{
First Record of Myotis occultus (Vespertilionidae) in the State of Guanajuato, Mexico
}

\author{
Gloria Magaña-Cota ${ }^{1}$, Yolanda Hortelano-Moncada ${ }^{2}$ and Miguel Briones-Salas ${ }^{3 *}$ \\ ${ }^{1}$ Museo de Historia Natural Alfredo Dugès, Universidad de Guanajuato. Lascuráin de Retana No. 5, Col. Centro, CP. 36000, \\ Guanajuato. Guanajuato, México. Email: gemc@ugto.mx (GM-C). \\ ${ }^{2}$ Departamento de Zoología, Instituto de Biología, Universidad Nacional Autónoma de México. Apdo. Postal 70-159, CP. 04510. \\ Ciudad de México, México. Email yolahm@ib.unam.mx (YH-M). \\ ${ }^{3}$ Laboratorio de Vertebrados Terrestres (Mastozoología), Centro Interdisciplinario de Investigación para el Desarrollo Integral \\ Regional, Unidad Oaxaca (CIIDIR-OAX), Instituto Politécnico Nacional. Hornos 1003, CP. 71230, Santa Cruz Xoxocotlán. Oaxaca, \\ México. Email: mbriones@ipn.mx (MB-S). \\ * Corresponding author
}

The bat, Myotis occultus (Vespertilionidae) is a rare and small-sized bat. The known distribution of M. occultus extends from the semi-arid areas of the southwestern United States down as far as the middle half of Mexico, not having beeing previously registered in the state of Guanajuato in Mexico. In August 2008 and February 2013, we collected bats using mist nets in the locality of Llanos de Santa Ana located within the municipality of Guanajuato, Gto., Mexico. We collected twelve specimens of M. occultus at the entrance of an abandoned mine in the municipality of Guanajuato, which represents the first documented record of the species in Guanajuato and confirms its presence for the state as predicted by potential distribution maps of the species. It is a small-sized bat, with few records in Mexico and, according to previous studies, its distribution is confirmed for the states of Chihuahua, Zacatecas, Mexico State, Mexico City, and now Guanajuato.

Myotis occultus, es un murciélago vespertiliónido raro y de tamaño pequeño. La distribución conocida de M. occultus incluye las áreas semiáridas del suroeste de Estados Unidos, hasta la mitad central de México, sin haberse registrado previamente en el estado de Guanajuato, México. En agosto del 2008 y febrero de 2013, se realizó colecta de quirópteros utilizando redes de niebla en la localidad de Llanos de Santa Ana, Municipio de Guanajuato, Gto., México. Se recolectaron doce ejemplares de Myotis occultus en la entrada de una mina abandonada, lo cual constituye el primer registro documentado de la especie y se confirma su presencia para el estado de Guanajuato, México, de acuerdo con la distribución potencial para la especie. Es un murciélago de tamaño pequeño, con pocos registros en México, que de acuerdo con estudios previos se distribuye en los estados de Chihuahua, Zacatecas, Estado de México, Ciudad de México y ahora Guanajuato.

Key words: geographical distribution; Guanajuato; protected natural area; small sized bat.

(c) 2018 Asociación Mexicana de Mastozoología, www.mastozoologiamexicana.org

\section{Introduction}

Thirty species of bats have been documented in Guanajuato (Sánchez et al. 2009; Sánchez et al. 2012; Sánchez 2014; Sánchez et al. 2016), a state located in central Mexico. However, no complete list showing the full diversity of bats in the state of Guanajuato yet exists; hence this number will undoubtedly increase as new studies are carried out in the area.

The bat, Myotis occultus (Vespertilionidae), is a smallsized vesper bat. This species differs from other species of Myotis from Guanajuato, M. thysanodes and $M$. velifer, for its medium size and different dorsal pelage coloration. M. thysanodes have big ears, and fringed uropatagium, whereas $M$. velifer has a small patch with few hairs (sometimes appearing as an almost-naked areas) in the middle part of the back, and both species have a well developed sagittal crest. M. occultus, is more similar in size to M. yumanensis, and both species lack a sagittal crest. M. occultus, has long, thick, and glossy fur on its back, which is black at the base and bright yellow at the tip (except for the ones on the base of the neck); it has large, dark brown or blackish ears with a long spear-shaped tragus, and $M$. yumanensis has dorsal hairs that are shorter with paler tips, pelage duller and not glossy, paler ears, and larger tragus having a semicircular border. In M. occultus, the braincase does not rise abruptly, and the middle and occipital regions are almost at the same level. In M. yumanensis the braincase rises at an abrupt angle from the rostrum, the mastoid breadth is smaller, and the calcaneum is not keeled. Dental formula of $M$. occultus is I 2/3, C 1/1, PM 3/3, M 3/3 = 38 (Ortega and Arita 2005; Medellín et al. 2008; Álvarez-Castañeda and Gónzalez-Ruiz 2015; Braun et al. 2015).

The species feeds on insects and migrates in winter to temperate regions (Humphrey 1982). The known distribution of M. occultus extends from the semi-arid areas of the southwestern United States down as far as the middle half of Mexico (Arroyo et al. 2008). It is a rare species with few records in Mexico, most of which have been documented in the states of Chihuahua (Anderson 1972), Zacatecas and Mexico State, as well as in Mexico City (Hall and Kelson 1959; Álvarez and Ramírez 1972; Urbano et al. 1987; Sánchez et al. 1989; Ortega and Arita 2005; Hortelano et al. 2016; RíosMuñoz et al. 2017).

Other studies report the presence of $M$. occultus in Aguascalientes (Chávez-Andrade et al. 2015) and Hidalgo (Mejenes-López et al. 2010, Ramírez-Pulido et al. 2017), but 
cite for this purpose other studies that are either unpublished (Aguascalientes) or report only a potential distribution within the borders of the state (Ortega and Arita 2005). In addition, a more recent checklist for Hidalgo, based on published papers, specimens in biological collections, and databases, does not include M. occultus (Sánchez-Rojas et al. 2016). Therefore, in the absence of verifiable, well-documented records, these states are not considered as part of the confirmed distribution of $M$. occultus.

This paper describes the first documented record in Guanajuato of the bat (Myotis occultus, Hollister 1909), based on 12 specimens caught in the locality of Llanos de Santa Ana in the municipality of Guanajuato, Mexico.

\section{Materials and methods}

Study Area. The locality of Llanos de Santa Ana is situated within the municipality of Guanajuato, Mexico, in the state of the same name. It is also located within the Protected Natural Area (PNA) of Cuenca de la Soledad, a state-level PNA classified as one requiring special attention in terms of ecological restoration, for being an important aquifer recharge area that feeds La Soledad reservoir, one of the main sources of water for the city of Guanajuato. The local vegetation corresponds to that of deserts and xeric shrublands, with a high rate of deforestation caused by the intense mining activity in the region.

On August 6, 2008, as part of a study of the bats in the area, we collected twelve specimens of $M$. occultus at the entrance of an abandoned mine ( $21^{\circ} 03^{\prime} 25^{\prime \prime} \mathrm{N},-101^{\circ} 16^{\prime} 27^{\prime \prime}$ W, 2,240 m.), located $4.25 \mathrm{~km} \mathrm{NW}$ of Guanajuato (Figure 1), by using a $12 \mathrm{~m} \times 2.5 \mathrm{~m}$ mist net that remained open from 18:00 $\mathrm{h}$ to $23: 00 \mathrm{~h}$. We identified individuals using keys for Mexican mammals (Medellín et al. 2008; Alvarez et al. 2015) and prepared the specimens for scientific study following the recommendations of Gannon et al. (2007). All specimens were deposited in the National Collection of Mammals (CNMA) at the Institute of Biology of the National Autonomous University of Mexico (UNAM) under catalog numbers CNMA 44523 to 44532 and 47305-47306. Prior to collecting the specimens, we first obtained the necessary permit (number FAUT-0070) from the Ministry of Environment and Natural Resources (SEMARNAT). Somatic and cranial measurements were registered following ÁlvarezCastañeda and Gónzalez-Ruiz (2015).

We obtained Cytochrome Oxidase I (COI) gene sequences for five of the specimens collected, CNMA 44523- 44527 (GU686195, GU686214, GU686212, GU686213, GU686193, respectively), which are available on the BOLD Systems website and GenBank for future studies but they were not used to corroborate the identity of the specimens.

\section{Results}

The twelve specimens collected were reproductively inactive males. The range and average external measurements (in $\mathrm{mm}$ ) of these individuals were: total length (TL): $71-84$, $=79.95$; length of tail (LT): $30-38,=34.5$; length of hind foot (LHF): 6 - 14, = 9.58; length of ear (LE): $11-14$, = 13.4; and length of forearm (LF: $31-36,=33.5$; Figure 2). The average cranial and mandibular measurements were: length of skull (LS): 13.70 - 14.34, = 13.98; cranial width (CW): 6.86 - 7.60, = 7.12; cranial height $(\mathrm{CH}): 5.96-6.58,=6.17$; zygomatic breadth (ZB): $7.72-8.28,=8.06$; mastoid breadth $(\mathrm{MB})$ : $6.08-7.06,=6.94$; interorbital breadth (IOB): $3.62-3.96$, = 3.79; breadth across upper molars (BAM): $5.20-5.24$, =

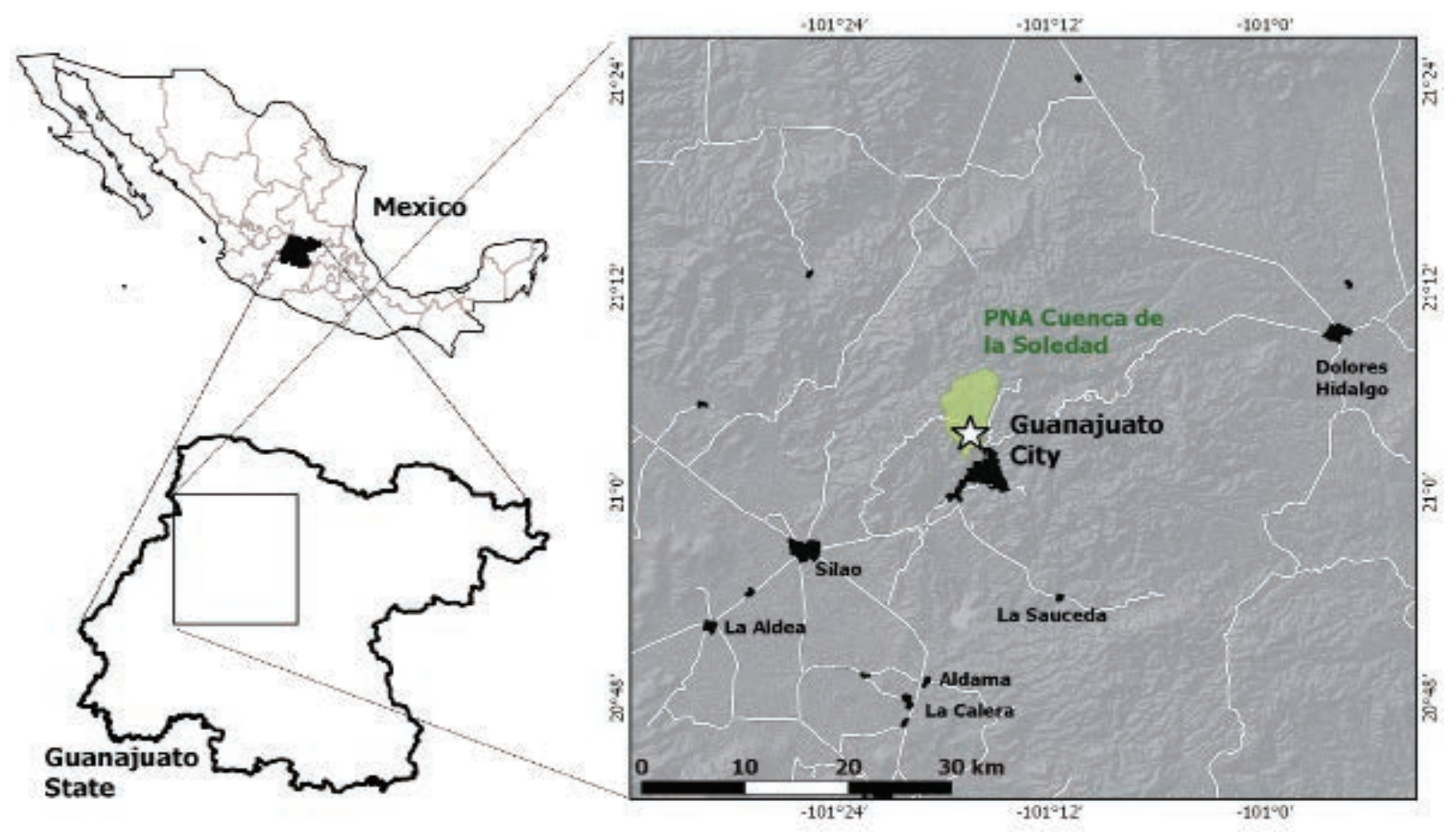

Figure 1. Geographic location of the collection site of Myotis occultus in the Protected Natural Area (PNA) Cuenca de la Soledad, Municipality of Guanajuato, Gto., Mexico. 
5.13; maxillary toothrow length (MAX): $5.09-6.01,=5.78$; condylobasal length (CBL): $11.25-12.00,=11.70$; and mandibular toothrow length (MAN: 6.26-6.58, =6.44; Figure 3).

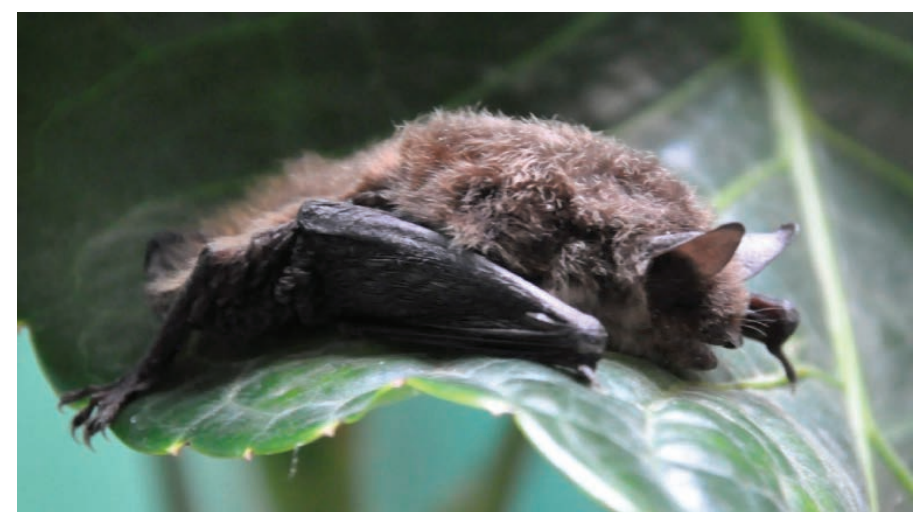

Figure 2. A specimen of Myotis occultus collected in the Protected Natural Area (PNA) of Cuenca de la Soledad, Guanajuato, Mexico (Photo Y. Hortelano).

\section{Discussion and Conclusions}

The presence of $M$. occultus in the state of Guanajuato is consistent with the potential distribution of the species (Ortega and Arita 2005). Therefore, this is the first record of $M$. occultus for the state supported with voucher specimens. In addition, we uploaded DNA sequences at GenBank for further studies.

Until now, the list of bats in the state of Guanajuato includes 30 species (Sánchez et al. 2016). However, this figure is still somehow low compared to that of areas that have undergone major urban development such as the Mexico City Metropolitan Area, where 28 species have been described (Sánchez et al. 1989; Hortelano-Moncada et al. 2016). Furthermore, the state of Guanajuato encompasses portions of two biogeographic regions: the Neartic and the Neotropical, in an area where the Sierra Madre Oriental, the Trans-Mexican Volcanic Belt, and the Mesa Central come together, a situation that provides a noteworthy diversity. We suggest that more exploration studies be done to obtain a better approximation of its biological diversity.

\section{Acknowledgments}

Sequences obtained with the support of the projects FCMUN UNAM Mammals of Mexico, Bold System and Project HB029 "Barcode of Specimens of the National Mammal Collection of the Institute of Biology, UNAM". We thank the following individuals and Institutions: University of Guanajuato's Research and Postgraduate Studies Support Office for assistance with the translation of the manuscript in special to B. J. McDougall. To F. A. Cervantes for his assistance in depositing the specimens in the CNMA and support in obtaining the sequences. To M. de la Paz Cruickshank, M. A. León and two anonymous reviewers, for their valuable comments and suggestions to improve the manuscript. To E. G. Batalla for helping with specimens determination and M. Lavariega for helping with map. M. Briones-Salas would like to thank the Secretaria de Investigación y Posgrado (SIP) and the system of Estímulos al Desempeño de los

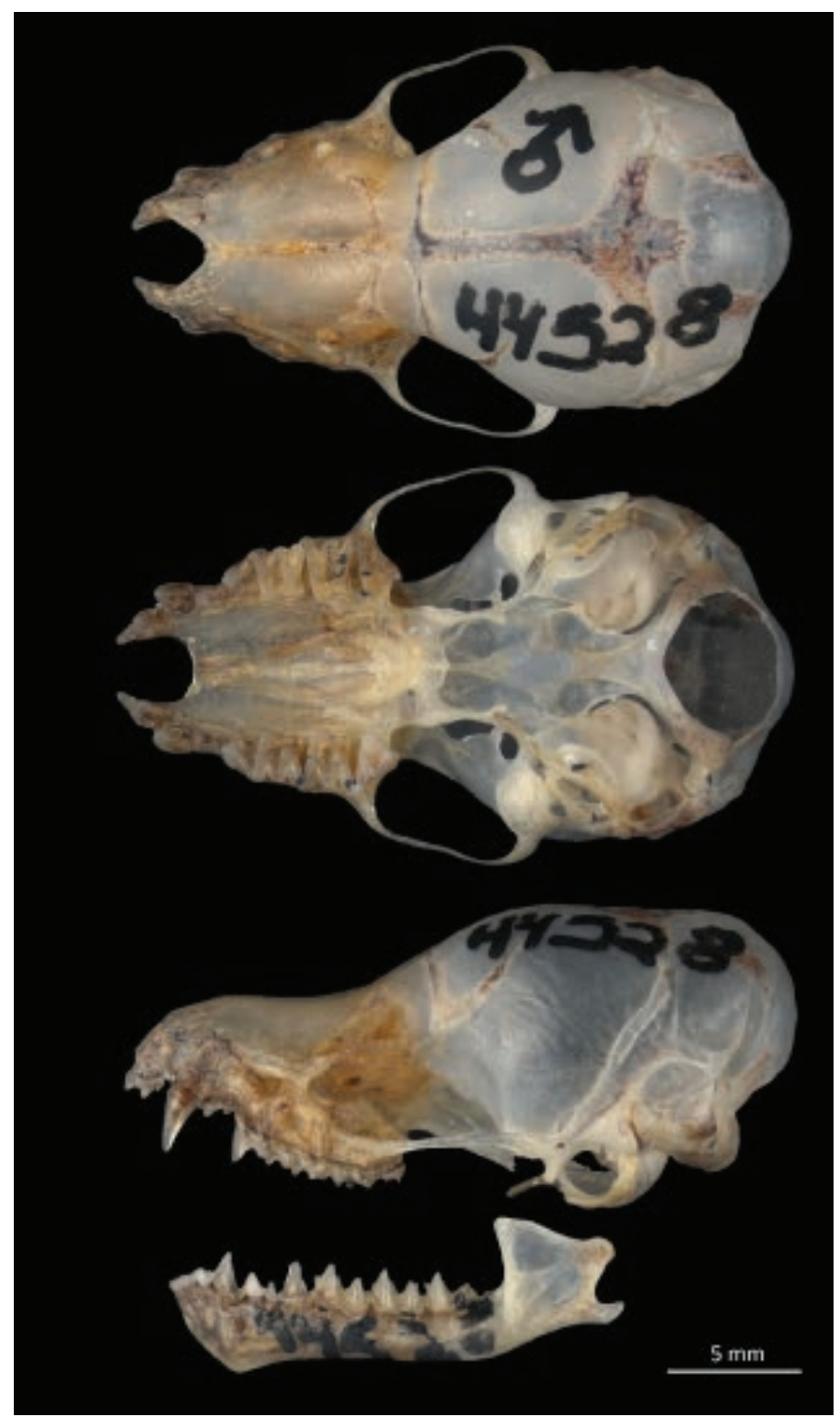

Figure 3. Dorsal, ventral, and lateral views of skull and lateral view of mandible of an adult male of Myotis occultus collected in the Protected Natural Area (PNA) of Cuenca de la Soledad, Municipality of Guanajuato, Gto., Mexico (Photo Carmen Loyola).

Investigadores (EDI) of Instituto Politécnico Nacional (IPN), as well as Sistema Nacional de Investigadores (SNI).

\section{Literature cited}

Álvarez, T., S. T. Álvarez-Castañeda, and J. C. López-Vidal. 1994. Clave para murciélagos mexicanos. Co-Edición No. 2. Centro de Investigaciones Biológicas del Noreste, S. C. y Escuela Nacional de Ciencias Biológicas, Instituto Politécnico Nacional. La Paz, México.

Álvarez, T., and J. Ramírez-Pulido. 1972. Notas acerca de murciélagos mexicanos. Anales de la Escuela Nacional de Ciencias Biológicas 19:167-178.

Álvarez-Castañeda, S. T., T. Álvarez and N. González-Ruiz. 2015. Guía para la identificación de los mamíferos de México en campo y laboratorio/keys for identifying Mexican Mammals in the field and in the laboratory. Centro de Investigaciones Biológicas del Noroeste, S. C. y Asociación Mexicana de Mastozoología, A. C. Guadalajara, México. 
Anderson, S. 1972. Mammals of Chihuahua: taxonomy and distribution. Bulletin of the American Museum of Natural History 148:149-410.

Arroyo-Cabrales, J., and S. T. Álvarez-Castañeda. 2008. Myotis occultus. In IUCN 2012. IUCN Red List of Threatened Species.

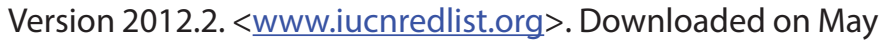
3, 2013.

Braun, J. K., B. Yang, S. B. González-Pérez, and M. A. Mares. 2015. Myotis yumanensis (Chiroptera:Vespertilionidae). Mammalian Species 47(918):1-14.

Chávez-Andrade, M., J. Luévano-Esparza, G. E. Quintero-Díaz, H. V. Bárcenas, and G. Ceballos. 2015. Mamíferos del Estado de Aguascalientes. Revista Mexicana de Mastozoología Nueva época. 1-22.

Gannon, W. L., R. S. Sikes, and The Animal Care and Use Committee of American Society of Mammalogists. 2007. Guidelines of the American Society of Mammalogists for the use of wild mammals in research. Journal of Mammalogy 88:809-823.

Hall, E. R., And K. R. Kelson. 1959. Mammals of North America. The Ronald Press Co. New York, U. S. A.

Hortelano-Moncada, Y., F. A. Cervantes, and R. Rojas Villaseñor. 2016. Riqueza y conservación de los mamíferos silvestres de la Ciudad de México. Pp. 179-220, in Riqueza y Conservación de los Mamíferos en México a Nivel Estatal (Briones-Salas, M., Y. Hortelano-Moncada, G. Magaña-Cota, G. Sánchez-Rojas, and J. E. Sosa-Escalante, eds.). Instituto de Biología, Universidad Nacional Autónoma de México, Asociación Mexicana de Mastozoología A. C. y Universidad de Guanajuato, Ciudad de México, México.

HumphreY, S. R. 1982. Bats, Vespertilionidae and Molossidae. Pp. 52-70, in Wild Mammals of North America, Biology, Management and Economics (Chapman, J. A., and G. A. Feldhamer, eds.). Johns Hopkins University Press, Baltimore, U.S.A.

Medellín, R. A., H. T. Arita, and O. Sánchez. 2008. Identificación de los murciélagos de México. Claves de campo. Segunda Edición. Instituto de Ecología, UNAM. Ciudad de México, México.

Mejenes-López, Sol de Mayo Araucana, M. Hernández-Bautista, J. Barragán-Torres, and J. Pacheco Rodríguez. 2010. Los mamíferos en el Estado de Hidalgo, México. Therya 1:161-188.

Ortega, J., And H. T. AritA. 2005. Myotis occultus. Pp. 289-290, in Los mamíferos silvestres de México (Ceballos, G., and G. Oliva, eds.). Fondo de Cultura Económica-CONABIO, Ciudad de México, México.

Piaggio, A. J., E. W. Valdez, M. A. Bogan, and G. S. Spicer. 2002. Systematics of Myotis occultus (Chiroptera: Vespertilionidae) inferred from sequences of two mitochondrial genes. Journal of Mammalogy 83:386-395.

Ríos-Muñoz, C. A., D. V. Espinosa-Martínez, C. Ballesteros-Barrera, G. Ameneyro-Cruz, G. López-Ortega, J. Arroyo-Cabrales, and L. LeónPaniagua. Mamíferos de Zacatecas. 2017. Revista Mexicana de Mastozoología Nueva época 1:1-23.

SÁNCHEZ, O. 2014. Sinopsis de los mamíferos silvestres del estado de Guanajuato, México, y comentarios sobre su conservación. Therya 5:369-422.

Sánchez, O., J. F. Charre-Medellín, G. Téllez-Girón, O. BáezMontes, And G. Magaña-CotA. 2016. Mamíferos silvestres de Guanajuato: actualización taxonómica y diagnóstico de conservación. Pp. 243-280, in Riqueza y Conservación de los mamíferos en México a Nivel Estatal (Briones-Salas, M., Y. Hortelano-Moncada, G. Magaña-Cota, G. Sánchez-Rojas, and J. E. Sosa Escalante, eds.). Instituto de Biología, Universidad Nacional Autónoma de México, Asociación Mexicana de Mastozoología, A. C., y Universidad de Guanajuato. Ciudad de México, México.

SÁnchez, O., G. López-O., And R. LóPez-Wilchis. 1989. Murciélagos de la Ciudad de México y sus alrededores. Pp. 141-165, in Ecología Urbana (Gío-Argaés, R., I. Hernández-R., and E. Sáinz-H., eds.). DDF, CONACYT, Universidad Nacional Autónoma de México, SEDUE, SEP, Sociedad Mexicana de Historia Natural, Universidad Autónoma Metropolitana. Ciudad de México, México.

Sánchez, O., G. Téllez-Girón, And G. Magaña-Cota. 2009. Registros adicionales de murciélagos para Guanajuato. Acta Universitaria 19:40-47.

Sánchez, O., C. Elizalde-Arellano, J. C. López-Vidal, G. MagañaCota, G. Téllez-Girón, F. Botello, and V. Sánchez-Cordero. 2012. Mamíferos Silvestres. in Comisión Nacional para el Estudio y Uso de la Biodiversidad (CONABIO). La Biodiversidad en Guanajuato: Estudio de Estado. CONABIO/Instituto de Ecología del Estado de Guanajuato. Guanajuato, México.

Sánchez-Rojas G., S. D. Hernández Flores, J. Castillo-Cerón, S. Mejenes-López, M. Aguilar-López, J. Bravo-Cadena, A. GarcíaBecerra, R. García-Morales, and D. Hernández-Silva. 2016. Riqueza, composición y conservación de los mamíferos del estado de Hidalgo, México. Pp. 281-310, in Riqueza y Conservación de los Mamíferos en México a Nivel Estatal (Briones-Salas, M., Y. Hortelano-Moncada, G. Magaña Cota, G. Sánchez-Rojas, and J. E. Sosa-Escalante, eds.). Instituto de Biología, Universidad Nacional Autónoma de México, Asociación Mexicana de Mastozoología A. C. y Universidad de Guanajuato. Ciudad de México, México.

Urbano G., O. Sánchez, G. Téllez and R. A. Medellín. 1987. Additional records of Mexican mammals. Southwestern Naturalist 32:134-137.

Associated editor: Rafael Avila

Submitted: Febreary 8, 2018; Reviewed: April 17, 2018;

Accepted: June 18, 2018; Published on line: July 7, 2018. 